\title{
Assessment of Physical and Chemical Stability of Different Magnesium Compounds in Tablets
}

\author{
CORINA MOISA ${ }^{1}$, DELIA MIRELA TIT ${ }^{1}$, DIANA UIVAROSAN ${ }^{1}$, OANA CADAR ${ }^{2}$, \\ LAVINIA CRISTINA MOLERIU ${ }^{3}$, GABRIELA CIOCA ${ }^{4}$, DANUT-EUGENIU MOSTEANU ${ }^{5}$, \\ LOTFI ALEYA ${ }^{6}$, SIMONA BUNGAU ${ }^{1 *}$ \\ ${ }^{1}$ University of Oradea, Faculty of Medicine and Pharmacy, 29 N. Jiga Str., 410028, Oradea, Romania \\ ${ }^{2}$ INCDO-INOE 2000, Research Institute for Analytical Instrumentation, 67 Donath Str., 400293, Cluj Napoca, Romania \\ ${ }^{3}$ Victor Babes University of Medicine and Pharmacy, Faculty of Medicine, Timisoara, Romania \\ ${ }^{4}$ Lucian Blaga University of Sibiu, Faculty of Medicine, 10 Victoriei Blvd., 550024, Sibiu, Romania \\ ${ }^{5}$ Land Forces Academy Nicolae Balcescu, Sibiu, Romania \\ ${ }^{6}$ Laboratoire Chrono-environnement, Université de Franche-Comte, Besançon, France.
}

Modern lifestyle, excessive chemicalization of agricultural products, excessive processing and refining of food, cause a decrease in daily intake of magnesium, cation with an extremely important role in prevention and treatment of many diseases. As a result, there arises the need for extra magnesium intake in the form of dietary supplements. In this study were evaluated the physical and chemical stability of magnesium-containing tablets, depending on the active compound and the excipients used. Magnesium tablets in the form of orotate, lactate, citrate, oxide and hydroxide were taken into study and physical and chemical stability were observed over the validity period, at 6 and at 12 months after expiry date. There were no changes in physical and chemical stability during the validity period of the studied tablets. At 6 months after the expiry date, were observed variations in chemical composition with decrease in magnesium concentration to $98 \%$ of the declared value, only in the case of tablets containing magnesium lactate. At 12 months, the magnesium concentration decreased in all analysed samples, with no statistically significant differences $(p<0.05)$ between the types of magnesium compounds - 95\% for the orotate, 93\% for the lactate, $90 \%$ for the oxide and hydroxide, respectively $85 \%$ for citrate. The results of this study indicate the therapeutically safety for using these tablets 6 months after the expiry date.

Keywords: tablets, magnesium compounds, physicochemical stability, validity period.

Magnesium is an essential element with multiple functions in the human body, being involved in the regulation of muscle contraction, glycaemic control, myocardial contraction and blood pressure as well as in neuromuscular management [1-4]. Also, magnesium has an important role in the production of energy, in the active transmembrane transport of other ions, in bone development [5], in many other processes and functions of the body. Therefore, the deficiency of this mineral in the human body is associated with a series of dysfunctions and numerous pathologies [6-9].

The required intake of magnesium is ensured by water consumption (10\%) and food, mainly of vegetable origin, the most important source being unprocessed cereals. Excessive chemicalization of vegetable, fruit and cereal crops, as well as the characteristics of the cultivation soil [10-12] have resulted in a decrease of magnesium quantity in food products over time by up to $30 \%$ [13]. Excessive processing and refining may result in a decrease of up to 85\% [13]. All these circumstances lead to a deficient magnesium amount in food and, implicitly, lower quantity than the recommended and necessary daily dose. Decrease in magnesium presence in food is associated with an increase in the incidence of cardiovascular disease among the population $[13,14]$.

To balance the intake and maintain an optimal magnesium level in the body, in some cases magnesium supplements are recommended; they contain magnesium in the form of different compounds and in various concentrations. Studies have shown that the composition of these supplements is very important for restoring the optimal quantity of magnesium in the body. Magnesium used to make food supplements is found in various forms: lactate, citrate, orotate, oxide, magnesium hydroxide and the most commonly used pharmaceutical forms are oral tablets. Depending on the type of magnesium compound and the excipients used to obtain the tablet, different intracellular absorption values are obtained in different organs [15-17]. For proper treatment, the advice of health professionals (physician, pharmacist) is important because they know both the active principles of the product and the potential drug interactions, new forms of pharmaceuticals appearing on the market, relevant issues for choosing the right treatment [18]. 
The restoration of the physiological level of magnesium depends not only on the amount / concentration of magnesium administered, but also on the extent of its absorption at the intracellular level. The use of these tablets in therapy requires good stability over time; numerous possible physical and chemical transformations of the medicinal product have the consequence of partial or total loss of pharmacological action. Due to these degradations, supplements / medications no longer correspond to the purpose for which they were developed and no longer provide therapeutic safety. Processes that can affect the stability of a drug include hydrolysis and oxidation, but photochemical decomposition can also occur [19,20]. The action of a drug and the stability of the pharmaceutical form is dependent on the structure of the active substance and the interactions with the excipients. Based on this stability, the validity period of medicinal products is set.

In this paper we evaluated the physical and chemical stability of tablets containing different magnesium compounds (orotate, lactate, citrate, oxide and hydroxide) during the validity period, as well as at 6 and at 12 months after the expiry date of the product.

\section{Experimental part \\ Material and method}

For all five types of magnesium compounds (orotate, lactate, citrate, oxide and hydroxide) twenty tablets were taken into study, from different batches and physical and chemical stability were observed for the validity period, at 6 and at 12 months after the tablets' expiry date.

To assess physical stability, the appearance, colour, smell and degradation of the tablets in aqueous medium at $\mathrm{pH}=6.8$, at $37{ }^{\circ} \mathrm{C}$, at 50 and $100 \mathrm{rpm}$ at different time intervals $(5,10,30,60$ and 120 minutes) were observed. As for the chemical stability, the variation in magnesium concentration of the compounds in the studied tablets, was observed during the validity period, at 6 and at 12 months after the expiry date.

The magnesium tablets (produced by four different manufacturers), containing nine excipients (microcrystalline cellulose, hydroxypropyl-methylcellulose, carboxymethylcellulose, hydroxypropyl methylcellulose, lactose monohydrate, magnesium stearate, starch, gum arabica, polyvinyl pyrrolidine, croscarmellose, titanium dioxide and talcum) usually found in pharmaceutical formulations, were used to perform this research. All reagents used in the experiments were of analytical degree, purchased from Merck (Germany).

\section{Study of the release of the magnesium ion}

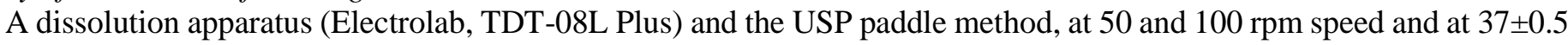
${ }^{\circ} \mathrm{C}$, were used to conduct dissolution tests for obtaining a pattern for magnesium release. The dissolution media $(900 \mathrm{~mL})$ used for the tests contained: simulated intestinal fluid (SIF) with $\mathrm{pH}=6.8$ ultrapure water (UW) with $\mathrm{pH}=6.998$, and buffer solution $\left(\mathrm{K}_{2} \mathrm{HPO}_{4}-\mathrm{NaOH}\right)$, the tests being carried out over definite periods of time $(5,10,30,60$ and $120 \mathrm{~min})$. The quantity of magnesium was $200 \mathrm{mg}$. Magnesium liberation from the active substance was also examined. At a fixed moment of time, a sample of $5 \mathrm{~mL}$ was taken, then filtered using a $0.45 \mu \mathrm{m}$ pore size filter; the magnesium content was determined with the use of an inductively coupled plasma optical emission spectrometer (ICP-OES) Optima 5300 DV (Perkin Elmer, USA). The equation $\mathrm{LOD}=3 \mathrm{sb} / \mathrm{m}$ (where $\mathrm{sb}$ was the standard deviation of 10 successive determination of blank and $\mathrm{m}$ was the slope of calibration curve) was used to calculate the limit of detection as being LOD=0.01 mg/L [21]. At the magnesium emission line $(285 \mathrm{~nm})$ were not revealed interferences with potassium, phosphorus and sodium. A 350i multiparameter (WTW, Weilheim, Germany) was used to determine the $\mathrm{pH}$. Each test was conducted three times. A Millipore Direct-Q3 UV Ultrapure water system (Millipore, Molsheim, France) produced the deionized water $(18.2 \mathrm{M} \Omega / \mathrm{cm}$ ) used to prepare all dilutions. A solution of $10 \%(\mathrm{v} / \mathrm{v}) \mathrm{HNO}_{3}$ was used to treat the glass vessels and PTFE overnight. Milli-Q water was used to rinse them before utilisation.

\section{Statistical analysis}

For the descriptive statistics were calculated the central tendency and dispersion parameters and some proper charts were made. The descriptive analysis was run in the Microsoft Excel program. The statistical tests were performed using the SPSSv17 program. The Mann - Whitney test was chosen for the case when there are two different groups, the ANOVA one Way test was used for more than two groups and the ANOVA bi-factorial test without replication was chosen when there are more than two times moments. The confidence level is set at $\alpha=0.05$.

\section{Results an discussions}

Table 1 shows the characteristics of the tablets used in this study, and Tables 2-4 show the amount of magnesium found in tablets, in UW and SIF, during the validity period, as well as at 6 and at 12 months after the expiry date of the studied product. 
Table 1

MAGNESIUM COMPOUNDS USED, MAGNESIUM/VALIDITY PERIOD AND EXCIPIENTS

\begin{tabular}{|c|c|c|c|}
\hline Sample & Mg compounds & $\begin{array}{c}\text { Concentrations of } \mathrm{Mg} \\
(\mathrm{mg} \mathrm{Mg} / \mathrm{tb})\end{array}$ & Excipients \\
\hline 1 & Orotate & 32.8 & $\begin{array}{c}\text { Silicon dioxide } \\
\text { Croscarmellose } \\
\text { Cellulose } \\
\text { Starch } \\
\text { Lactose } \\
\end{array}$ \\
\hline 2 & Hydroxide & 90 & $\begin{array}{c}\text { Starch } \\
\text { Croscarmellose } \\
\text { Lactose } \\
\end{array}$ \\
\hline 3 & Lactate & 48 & $\begin{array}{c}\text { Gum arabic } \\
\text { Talc } \\
\text { Titanium dioxide }\end{array}$ \\
\hline 4 & Oxide & 250 & $\begin{array}{c}\text { Cellulose } \\
\text { Polyvinyl pyrrolidone } \\
\text { Hydroxypropyl methyl cellulose }\end{array}$ \\
\hline 5 & Citrate & 250 & $\begin{array}{c}\text { Calcium carbonate } \\
\text { Cellulose } \\
\text { Carboxymethyl cellulose } \\
\text { Hydroxypropyl methyl cellulose } \\
\text { Talc } \\
\text { Polyvinyl pyrrolidone }\end{array}$ \\
\hline
\end{tabular}

Table 2

QUANTITY OF MAGNESIUM (mg/tb) IN UW AND SIF, DURING VALIDITY PERIOD

\begin{tabular}{|c|c|c|c|c|c|c|c|c|c|c|}
\hline \multirow{2}{*}{ Sample } & \multicolumn{10}{|c|}{ Centrifugation time (min) } \\
\hline & 5 & 10 & 30 & 60 & 120 & 5 & 10 & 30 & 60 & 120 \\
\hline \multicolumn{11}{|c|}{ At $50 \mathrm{rpm}$} \\
\hline \multicolumn{6}{|c|}{ In UW } & \multicolumn{5}{|c|}{ In SIF } \\
\hline 1 & 18.3 & 32.8 & 32.8 & 32.8 & 32.8 & 18.1 & 32.8 & 32.8 & 32.8 & 32.8 \\
\hline 2 & 18.2 & 90 & 90 & 90 & 90 & 72.3 & 89.5 & 90 & 90 & 90 \\
\hline 3 & 73.2 & 47.5 & 48 & 48 & 48 & 39.5 & 45.9 & 48 & 48 & 48 \\
\hline 4 & 199.8 & 243.2 & 250 & 250 & 250 & 201.3 & 245.6 & 250 & 250 & 250 \\
\hline 5 & 193.5 & 220.1 & 250 & 250 & 250 & 195.6 & 222.9 & 250 & 250 & 250 \\
\hline \multicolumn{11}{|c|}{ At $100 \mathrm{rpm}$} \\
\hline \multicolumn{6}{|c|}{ In UW } & \multicolumn{5}{|c|}{ In SIF } \\
\hline 1 & 32.8 & 32.8 & 32.8 & 32.8 & 32.8 & 32.8 & 32.8 & 32.8 & 32.8 & 32.8 \\
\hline 2 & 88.8 & 90 & 90 & 90 & 90 & 90 & 90 & 90 & 90 & 90 \\
\hline 3 & 46.3 & 48 & 48 & 48 & 48 & 48 & 48 & 48 & 48 & 48 \\
\hline 4 & 248.3 & 250 & 250 & 250 & 250 & 249.5 & 250 & 250 & 250 & 250 \\
\hline 5 & 247.6 & 250 & 250 & 250 & 250 & 248.3 & 250 & 250 & 250 & 250 \\
\hline
\end{tabular}

Table 3

QUANTITY OF MAGNESIUM (mg/tb) IN UW, AT 6 AND AT 12 MONTHS FROM THE EXPIRY DATE OF PHARMACEUTICAL PRODUCT

\begin{tabular}{|c|c|c|c|c|c|c|c|c|c|c|}
\hline \multirow{2}{*}{ Sample } & \multicolumn{10}{|c|}{ Centrifugation time (min) } \\
\hline & 5 & 10 & 30 & 60 & 120 & 5 & 10 & 30 & 60 & 120 \\
\hline \multicolumn{11}{|c|}{ At 6 months after expiry date } \\
\hline 1 & 15.6 & 22.3 & 32.8 & 32.8 & 32.8 & 17.1 & 26.3 & 32.8 & 32.8 & 32.8 \\
\hline 2 & 31.8 & 51.5 & 90 & 90 & 90 & 35.6 & 55.2 & 90 & 90 & 90 \\
\hline 3 & 18.1 & 28.6 & 48 & 48 & 48 & 22.1 & 32.1 & 48 & 48 & 48 \\
\hline 5 & 89.3 & 120.1 & 175.6 & 211.3 & 245 & 95.6 & 125.6 & 180.5 & 215.1 & 245 \\
\hline \multicolumn{11}{|c|}{ At 12 months after expiry date } \\
\hline \multicolumn{6}{|c|}{ At $50 \mathrm{rpm}$} & \multicolumn{5}{|c|}{ At $100 \mathrm{rpm}$} \\
\hline 1 & 12.3 & 21.3 & 31.16 & 31.16 & 31.16 & 15.8 & 25.8 & 31.16 & 31.16 & 31.16 \\
\hline 2 & 29.4 & 42.5 & 83.7 & 83.7 & 83.7 & 35.2 & 46.3 & 83.7 & 83.7 & 83.7 \\
\hline
\end{tabular}


Table 4

QUANTITY OF MAGNESIUM (mg/tb) IN SIF, AT 6 AND AT 12 MONTHS AFTER THE EXPIRY DATE OF THE PHARMACEUTICAL PRODUCT

\begin{tabular}{|c|c|c|c|c|c|c|c|c|c|c|}
\hline \multirow{2}{*}{ Sample } & \multicolumn{10}{|c|}{ Centrifugation time (min) } \\
\hline & 5 & 10 & 30 & 60 & 120 & 5 & 10 & 30 & 60 & 120 \\
\hline \multicolumn{11}{|c|}{ At 6 months after expiry date } \\
\hline \multicolumn{6}{|c|}{ At $50 \mathrm{rpm}$} & \multicolumn{5}{|c|}{ At $100 \mathrm{rpm}$} \\
\hline 1 & 18.9 & 27.5 & 32.8 & 32.8 & 32.8 & 17.1 & 26.3 & 32.8 & 32.8 & 32.8 \\
\hline 2 & 34.9 & 60.3 & 90 & 90 & 90 & 35.6 & 55.2 & 90 & 90 & 90 \\
\hline 3 & 34.1 & 39.7 & 48 & 48 & 48 & 22.1 & 32.1 & 48 & 48 & 48 \\
\hline 4 & 123.5 & 133.1 & 190.5 & 240.2 & 250 & 102.9 & 140.2 & 195.6 & 241.5 & 250 \\
\hline 5 & 98.6 & 129.7 & 190.4 & 219.5 & 245 & 95.6 & 125.6 & 180.5 & 215.1 & 245 \\
\hline \multicolumn{11}{|c|}{ At 12 months after expiry date } \\
\hline \multicolumn{6}{|c|}{ At $50 \mathrm{rpm}$} & \multicolumn{5}{|c|}{ At $100 \mathrm{rpm}$} \\
\hline 1 & 19.2 & 28.6 & 32.8 & 32.8 & 32.8 & 12.8 & 25.6 & 31.16 & 31.16 & 31.16 \\
\hline 2 & 35.2 & 65.3 & 90 & 90 & 90 & 32.3 & 56.5 & 83.7 & 83.7 & 83.7 \\
\hline 3 & 35.6 & 40.3 & 48 & 48 & 48 & 16.6 & 18.4 & 43.2 & 43.2 & 43.2 \\
\hline 4 & 133.2 & 145.3 & 195.1 & 244.5 & 250 & 56.3 & 72.5 & 156.3 & 200.5 & 225 \\
\hline 5 & 102.5 & 135.4 & 198.6 & 221.8 & 245 & 72.2 & 101.3 & 155.6 & 175.6 & 212.5 \\
\hline
\end{tabular}

In the beginning of the analysis, a descriptive statistic was run, in order to characterize the database and obtain as much information as possible. After this characterization, the study hypothesis can be formulated. So, for the descriptive analysis, the central tendency and dispersion parameters for the quantity of magnesium in validity period, in UW and SIF (Table 5), were calculated, and the magnesium compounds used, magnesium concentrations/validity period and excipients were plotted (Figure 1).

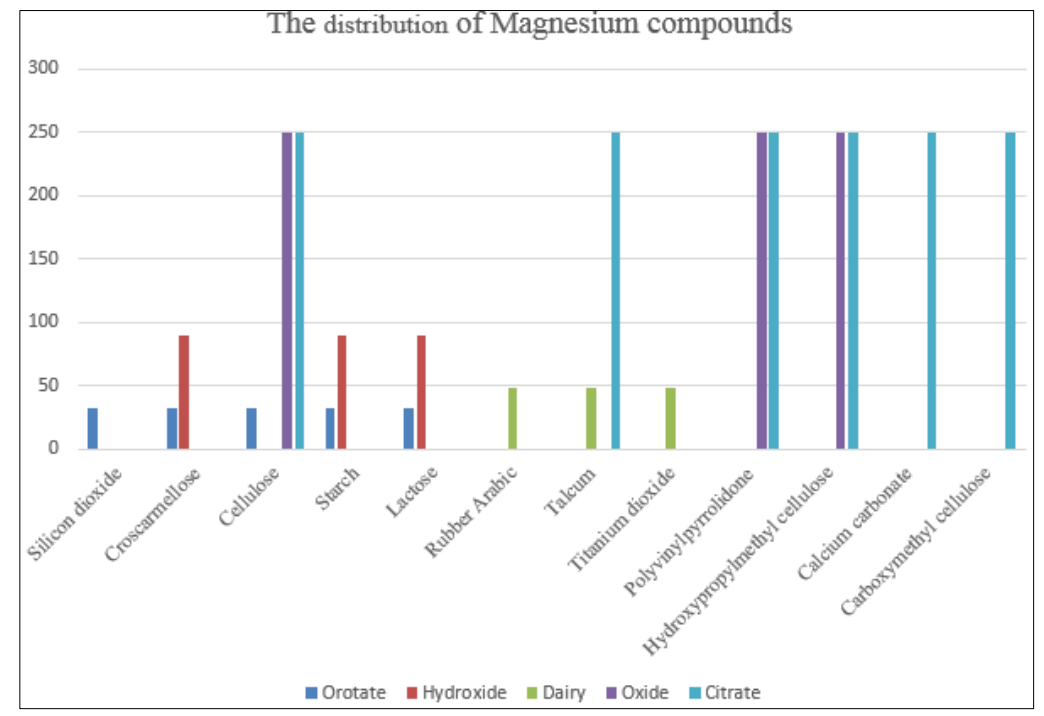

Fig. 1. The magnesium compounds used, magnesium concentrations/validity and excipients

Table 5

THE CENTRAL TENDENCY AND DISPERSION PARAMETERS FOR THE QUANTITY OF MAGNESIUM IN VALIDITY PERIOD, IN UW AND SIF

\begin{tabular}{|c|c|c|c|c|c|}
\hline Time points (min) & 5 & 10 & 30 & 60 & 120 \\
\hline Statistics & \multicolumn{5}{|c|}{ UW 50 rpm } \\
\hline Mean & 100.6 & 126.72 & 134.16 & 134.16 & 134.16 \\
\hline Standard Error & 40.48757 & 44.00713 & 48.21064 & 48.21064 & 48.21064 \\
\hline Median & 73.2 & 90 & 90 & 90 & 90 \\
\hline Mode & - & - & 250 & 250 & 250 \\
\hline Standard Deviation & 90.53295 & 98.40293 & 107.8023 & 107.8023 & 107.8023 \\
\hline Sample Variance & 8196.215 & 9683.137 & 11621.33 & 11621.33 & 11621.33 \\
\hline
\end{tabular}




\begin{tabular}{|c|c|c|c|c|c|}
\hline Range & 181.6 & 210.4 & 217.2 & 217.2 & 217.2 \\
\hline Minimum & 18.2 & 32.8 & 32.8 & 32.8 & 32.8 \\
\hline Maximum & 199.8 & 243.2 & 250 & 250 & 250 \\
\hline Count & 5 & 5 & 5 & 5 & 5 \\
\hline Statistics & \multicolumn{5}{|c|}{ UW $100 \mathrm{rpm}$} \\
\hline Mean & 105.36 & 127.34 & 134.16 & 134.16 & 134.16 \\
\hline Standard Error & 38.9824 & 44.788 & 48.21064 & 48.21064 & 48.21064 \\
\hline Median & 72.3 & 89.5 & 90 & 90 & 90 \\
\hline Mode & - & & 250 & 250 & 250 \\
\hline Standard Deviation & 87.1673 & 100.149 & 107.8023 & 107.8023 & 107.8023 \\
\hline Sample Variance & 7598.138 & 10029.82 & 11621.33 & 11621.33 & 11621.33 \\
\hline Range & 183.2 & 212.8 & 217.2 & 217.2 & 217.2 \\
\hline Minimum & 18.1 & 32.8 & 32.8 & 32.8 & 32.8 \\
\hline Maximum & 201.3 & 245.6 & 250 & 250 & 250 \\
\hline Count & 5 & 5 & 5 & 5 & 5 \\
\hline Statistics & \multicolumn{5}{|c|}{ SIF $50 \mathrm{rpm}$} \\
\hline Mean & 132.76 & 134.16 & 134.16 & 134.16 & 134.16 \\
\hline Standard Error & 47.92574 & 48.21064 & 48.21064 & 48.21064 & 48.21064 \\
\hline Median & 88.8 & 90 & 90 & 90 & 90 \\
\hline Mode & - & 250 & 250 & 250 & 250 \\
\hline Standard Deviation & 107.1652 & 107.8023 & 107.8023 & 107.8023 & 107.8023 \\
\hline Sample Variance & 11484.38 & 11621.33 & 11621.33 & 11621.33 & 11621.33 \\
\hline Range & 215.5 & 217.2 & 217.2 & 217.2 & 217.2 \\
\hline Minimum & 32.8 & 32.8 & 32.8 & 32.8 & 32.8 \\
\hline Maximum & 248.3 & 250 & 250 & 250 & 250 \\
\hline Count & 5 & 5 & 5 & 5 & 5 \\
\hline Statistics & \multicolumn{5}{|c|}{ SIF $100 \mathrm{rpm}$} \\
\hline Mean & 133.72 & 134.16 & 134.16 & 134.16 & 134.16 \\
\hline Standard Error & 47.94674 & 48.21064 & 48.21064 & 48.21064 & 48.21064 \\
\hline Median & 90 & 90 & 90 & 90 & 90 \\
\hline Mode & - & 250 & 250 & 250 & 250 \\
\hline Standard Deviation & 107.2122 & 107.8023 & 107.8023 & 107.8023 & 107.8023 \\
\hline Sample Variance & 11494.45 & 11621.33 & 11621.33 & 11621.33 & 11621.33 \\
\hline Range & 216.7 & 217.2 & 217.2 & 217.2 & 217.2 \\
\hline Minimum & 32.8 & 32.8 & 32.8 & 32.8 & 32.8 \\
\hline Maximum & 249.5 & 250 & 250 & 250 & 250 \\
\hline Count & 5 & 5 & 5 & 5 & 5 \\
\hline
\end{tabular}

For the statistical analysis three different tests were used: Mann - Whitney, ANOVA one Way and ANOVA bi factorial; in all tests was considered $\alpha=0.05$ as the confidence level.

As it is presented in Tables 2-4, there are three circumstances: differences in the magnesium concentration in UW and SIF in the validity term/period, differences in the quantity of magnesium at 6 months or at 12 months after the validity term/period is over in the UW case, respectively in the SIF case. For this purpose, several Mann - Whitney tests were applied, to see if there are differences between the magnesium concentration at $50 \mathrm{rpm}$ in the UW or SIF procedure for each time moment (at 5, 10, 30, 60120 minutes); there are no significant differences ( $p>0.05)$ in all cases, in some cases the $p$ - 
value being almost one. Also, there were observed the differences between the magnesium concentration for each time moment (at 5, 10, 30, 60120 minutes) in the case of $50 \mathrm{rpm}$, respectively $100 \mathrm{rpm}$. In all cases, the p value was higher than $0.05 \mathrm{so}$, it can be said that there are no differences in the magnesium concentration in the case of $50 \mathrm{rpm}$ compared with $100 \mathrm{rpm}$. The same hypothesis was run in the scenarios where the validity term/period is over (6 or 12 month) for UW or SIF. In these cases, the p values obtained were higher than 0.05 . So, there are no significant differences between the tested samples.

The ANOVA one Way test was applied to find if there are significant differences in magnesium concentration when UW was at $50 \mathrm{rpm}$ and at $100 \mathrm{rpm}$, and SIF was at 50 or at $100 \mathrm{rpm}$ respectively, in the validity term/period or when the validity period/term was over with 6 or 12 months. In all three cases, a p value higher than 0.05 was obtained, so it can be concluded that there are no significant differences.

In the last part of the analysis, ANOVA bi-factorial test was applied, in order to determine differences between the five time moments, in all cases (in the case of UW at $50 \mathrm{rpm}$, UW at $100 \mathrm{rpm}$, SIF at $50 \mathrm{rpm}$ or SIF at $100 \mathrm{rpm}$, in the validity term/ period, after 6 month and after 12 month the validity term/period is over). In all cases, p values higher than 0.05 were obtained, so the observed differences are not statistically significant.

The results obtained from the physical stability study indicate no changes in appearance, colour, smell of the tablets containing magnesium compounds throughout the study period. Regarding the decomposition of the tablets in the aqueous medium, were observed differences in the magnesium release rate of the tablets. These variations are determined by the nature of the excipients used in the formulation of the tablets. Tablets containing cellulose derivatives excipients (carboxymethyl cellulose, hydroxypropyl-methyl cellulose) degrade over a longer period of time compared to tablets that do not have these compounds.

As regards chemical stability, magnesium concentration in the tablets is found $100 \%$ for the entire validity period; In the case of compounds that contain magnesium orotate, lactate, hydroxide and oxide, the magnesium concentration remains unchanged even 6 months after the tablets' expiry date. For tablets containing magnesium citrate, there is a decrease in magnesium concentration to $98 \%$ of the value reported for the tablet at 6 months after the tablets have expired.

Analyzes on tablets at 12 months after the expiry date indicate a decrease in magnesium concentration for all the studied compounds, but there are differences in the magnesium concentration found in each tablet. Thus, in the case of compounds containing magnesium orotate, is found $95 \%$ of the magnesium declared per tablet; in the case of magnesium lactate is found $93 \%$ of the declared value; for magnesium oxide and hydroxide $90 \%$ of the declared value is found; in the case of magnesium citrate, is found $85 \%$ of the amount of magnesium declared per tablet.

To better understand the risks that may occur, such as chemical contamination, drug - food interactions or drug - drug interactions and dose dumping, an important issue in evaluating the best formulation is in vitro dissolution study [22-24].

The drug release rate depends on factors like: drug composition (stability, interaction with matrix, solubility), material matrix (degradation, structure, composition, swelling,), and release medium (ionic strength, pH, enzymes, temperature) [2527]. To formulate unit doses and other pharmaceutical products the most commonly used are cellulose and cellulose derivatives. A powerful effect on drug release is given by the molecular weight, degree of substitution, polymer content, concentration and particle size. The polymer concentration and drug/polymer ratio are the most important factors affecting the drug release rate of the cellulose matrices [28].

The present study focuses on the evaluation of magnesium release from tablets on the market that contain cellulose and/or its derivatives, using simulated intestinal fluid (SIF, phosphate buffer, $\mathrm{pH}=6.8$, enzyme free) and ultrapure water (UW) as dissolution media at various time intervals.

To predict in vivo performance essential means both in terms of stability and quality are considered in vitro dissolution studies. In vitro magnesium dissolution conduct in simulated intestinal fluid $(\mathrm{pH}=6.8)$ and ultrapure water for 5, 10, 30, 60, and 120 min time period, with a USP reference dissolution apparatus, was studied for four brands of tablets on the market with the same active compound and different excipients.

To obtain the therapeutic effect is important to release the active substance from the tablet. An important role in this process is held by the excipients used for compression. Depending on the nature of the excipients, the medicinal substance is released more rapid (maximum 15 minutes), or in the case of using delaying excipients, a prolonged or delayed release of the active substance (up to several hours) is obtained. Cellulose derivatives used as excipients in tablet formulation alter their properties in aqueous medium, the main modification being swelling. This allows the formation of a gel around the tablet and depending on the hydration degree of the gel and the water solubility of the active substance, it will be released from the tablet at a certain rate and over a certain period of time. Another factor contributing to the release of the active substance from the tablet is the erosion of the tablet under the action of gastric juices and implicitly of the $\mathrm{pH}$ [29].

In the case of the studied tablets, only samples 1,2 and 3 do not have cellulose derivatives (carboxymethylcellulose, hydroxypropyl-methylcellulose) in their composition, and in samples 4 and 5 these retardation excipients are found. This explains the prolonged release of magnesium from the tablets corresponding to samples 4 and 5 as compared to samples 1 , 
2 and 3. As regards the difference in magnesium release of the first three samples, the excipients have an important used for compression (disaggregates, binders) and the compression force of the compressing machine. All these elements are closely related to the physico-chemical properties of the active substance: orotate, hydroxide, lactate.

A quicker release of the active substance from the tablet leads to rapid therapeutic effect and implicitly to a lower irritation of gastric mucosa. Maintaining physical properties of appearance, colour and smell throughout the study indicates good physical stability of all the tablets on which determinations were made. Regarding tablet disintegration, there is a delay in the release of the active substance, with the increase of the period from the expiry date of the samples. A possible explanation may be related to the physical and chemical changes occurring within the tablet, between its components, which cause changes of the initial binding between the components.

For samples 1, 2 and 3, magnesium release from tablets takes place over the first 30 minutes, indicating a good disintegration of the tablets. For all tablets, increasing the rotation speed positively influences the release of magnesium from the tablet, even if not totally, as it happens at 12 months after the expiry date. Taking into account the results obtained, for fast recovery of magnesium deficiency it is possible to administer dietary supplements which do not contain excipients of retardation in the composition and contain magnesium in the form of orotate, hydroxide and lactate. The chemical structure of these magnesium compounds makes it possible to obtain tablets that present good physical and chemical stability even 6 months after the expiry date.

Tablets containing cellulose derivatives can be used for maintenance treatment after a minimum level of magnesium has been restored in the body. Release of the magnesium oxide and citrate from such tablets takes place within a few hours and lasts longer as compared to the immediate release tablets. The decrease in magnesium concentration over time is explained by modifying the stability of the tablets over time beyond the expiry date. The stability of these compounds is influenced by the chemical structure of each, as all the tablets have been stored under normal storage conditions (temperature, humidity, light) throughout the study.

\section{Conclusions}

Considering the results obtained from the physical and chemical stability studies performed, good stability of all the studied compounds can be observed over a longer period than the manufacturer's stated validity period mentioned on the package and on the product leaflet. This indicates the therapeutic safety when using these tablets after 6 months from the expiry date. Moreover, compounds containing magnesium orotate or lactate provide therapeutic safety even 12 months after the expiry date indicated by the manufacturer.

\section{References}

1.DIACONU, C.C., DRAGOI, C.M., BRATU, O.G., NEAGU, T.P., PANTEA STOIAN, A., COBELSCHI, P.C., NICOLAE, A.C., IANCU, M.A., HAINAROSIE, R., STANESCU, A.M.A., SOCEA, B., Farmacia, 2018, 66, no. 3, p. 408.

2.DIACONU, C.C., MANEA, M., IANCU, M.A., STANESCU, A.M.A., SOCEA, B., SPINU, D.A., MARCU, D., BRATU, O.G., Rev. Chim. 69, no. 5, 2018, p. 1071.

3.DIACONU, C.C., STANESCU, A.M.A., PANTEA STOIAN, A., TINCU, R.C., COBILINSCHI, C., DRAGOMIRESCU, R.I.F., SOCEA, B., SPINU, D.A., MARCU, D., SOCEA, L.I., BRATU, O.G., Rev. Chim., 69, no. 6, 2018, p. 1367.

4.MANEA, M., MARCU, D., PANTEA STOIAN, A., GAMAN, M.A., GAMAN, A.M., SOCEA, B., NEAGU, T.P., STANESCU, A.M.A., BRATU, O.G., DIACONU, C.C., Rev. Chim., 69, no. 11, 2018, p. 4180.

5.DUMitru, N., COCOlOS, A., CARAGHEORGHEOPOL, A., DUMITRACHE, C., BRATU, O.G., NEAGU, T.P, DIACONU, C.C., GHEMIGIAN, A., Rev. Chim., 69, no. 7, 2018, p. 1706.

6.HARTWIG, A., Mutat Res., 475, 2001, p. 113.

7.TOUYZ, R.M., Front. Biosci., 9, 2004, p. 1278.

8.BARABAS, R., RIGO, M., ENISZNE-BODOGH, M., MOISA, C., CADAR, O., Studia UBB Chem., LXIII, nr. 3, 2018, p. 137.

9.MAGUIRE, M.E., COWAN, J.A., Biometals, 15, 2002, p. 203.

10.SAMUEL, A.D., BUNGAU, S., TIT, D.M., MELINTE (FRUNZULICA), C.E., PURZA, L., BADEA, G.E., Rev. Chim., 69, no. 10, 2018, p. 2608 11.SAMUEL, A.D., BREJEA, R., DOMUTA, C., BUNGAU, S., CENUSA, N., TIT, D.M., J. Environ. Prot. Ecol., 18, nr. 3, 2017 , p. 871.

12.SAMUEL, A.D., TIT, D.M., MELINTE (FRUNZULICA), C.E., IOVAN, C., PURZA, L., GITEA, M., BUNGAU, S., Rev. Chim., 68, no. 10, 2017, p. 2243.

13.ROSANOFF, A., Plant Soil, 368, nr. 1-2, 2012, p. 139.

14.***Unitated States Department of Agriculture, USDA Food Composition Databases, Agricultural Research Service. 2001. USDA National Nutrient Database for Standard Reference legacy release https://ndb.nal.usda.gov/ndb/ (accesed in 5 May 2019)

15.MOISA, C., VICAS, L., GANEA, M., LEVEI, E., CADAR, O., BERCE, C., Farmacia, 66, nr. 1, 2018, p. 176.

16.MOISA, C., HOAGHIA, A., SIMEDRU, D., CADAR, O., Studia UBB Chemia, LXI, nr. 3, 2016, p. 441.

17.MOISA, C., CADAR, O., BARABAS, R., VICAȘ, L., HOAGHIA, A., LEVEI, E., JURCA, C., BERCE, C., Farmacia, 67, nr. 2 , 2019 , p. 274.

18.MOISA, C., VLAD, A.M., TEUSDEA, A., CADAR, O., HOAGHIA, A., STAN, R.L., TAEREL, A., JURCA, C., VICAS, L., Farmacia, 66, nr. 6, 2018, p. 1081.

19.BUNGAU S., TIT D. M., IOVAN C., COPOLOVICI L., BOSCENCU R., CIOCA G., COPOLOVICI D., Rev. Chim., 68, no. 11, 2017, p. 2495 20.BUNGAU S., BALDEA I., COPOLOVICI L., Rev. Chim., 54, no. 3, 2003, p.213

20.CADAR, O., MICLEAN, M., SENILA, M., HOAGHIA, A., SAGER, M., Studia UBB Chemia, 60, nr. 4, 2015 , p. 77.

21.GAO, Z., AAPS PharmSciTech., 10, nr. 4, 2009, p. 1401. doi: 10.1208/s12249-009-9339-6

Rev.Chim. $71 \bullet$ no. 2 $2020 \bullet$ https://revistadechimie.ro 
22.ABDEL-DAIM M. M., ABO-EL-SOOUD K., ALEYA L., BUNGAU S. G., NAJDA A., SALUJA R., Oxid. Med. Cell. Longev., 2018, 2018, ID 6276438. https://doi.org/10.1155/2018/6276438

23.CIOCA, G., BACAITA, E.S., AGOP, M., LUPASCU URSUlESCU, C., Comput. Math. Methods. Med., 2017, 2017, ID 5748273

24.PAUN, V.A., OCHIUZ, L., HORTOLOMEI, M., CRETEANU, A., STOIERIU, I., GHICIUC, C.M., SERBAN, G.T., ZEGAN, G., CIOCA, G., Mat. Plast., 53, no. 4, 2016, p. 699.

25.PAUN, V.A., POPA, M., DESBRIERES, J., PEPTU, C.A., DRAGAN, S.V., ZEGAN, G., CIOCA, G., Mat. Plast., 53, no. 4, 2016 , p.590.

26.CIOCA, G., AGOP, M., POPA, M., BUNGAU, S., BUTUC, I., Rev.Chim., 68, no. 12, 2017, p. 2925.

27.KAMEL, S., ALI, N., JAHANGIR, K., SHAH, S.M., EL-GENDY, A.A., Express Polymer Lett., 11, 2008 , p. 758.

28.ZHAO, D., WANG, T., NAHAN, K., GUO, X., ZHANG, Z., DONG, Z., CHEN, S., CHOU, D.T., HONG, D., KUMTA, P.N., HEINMAN, W.R., Acta Biomater., 50, 2017, p. 556.

Manuscript received: 4.07.2019 